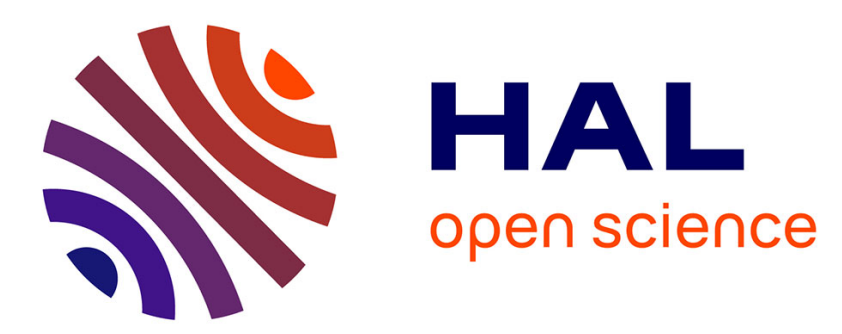

\title{
Occurrence of biomarkers and straight-chain biopolymers in humin: implication for the origin of soil organic matter.
}

Eric Lichtfouse, Claudette Leblond, Martine da Silva, Françoise Béhar

\section{- To cite this version:}

Eric Lichtfouse, Claudette Leblond, Martine da Silva, Françoise Béhar. Occurrence of biomarkers and straight-chain biopolymers in humin: implication for the origin of soil organic matter.. Die Naturwissenschaften, 1998, 85 (10), pp.449-452. 10.1007/s001140050538 . hal-00193825

\section{HAL Id: hal-00193825 \\ https://hal.science/hal-00193825}

Submitted on 4 Dec 2007

HAL is a multi-disciplinary open access archive for the deposit and dissemination of scientific research documents, whether they are published or not. The documents may come from teaching and research institutions in France or abroad, or from public or private research centers.
L'archive ouverte pluridisciplinaire HAL, est destinée au dépôt et à la diffusion de documents scientifiques de niveau recherche, publiés ou non, émanant des établissements d'enseignement et de recherche français ou étrangers, des laboratoires publics ou privés. 
Revised version

Naturwissenschaften 85, 497-501, 1998.

doi: $10.1007 / \mathrm{s} 001140050538$

Correspondence: Dr. Eric Lichtfouse, INRA-CMSE-PME, 17, rue Sully, 21000 Dijon, France

Eric.Lichtfouse@dijon.inra.fr

\title{
Occurrence of biomarkers and straight-chain biopolymers in humin: implication for the origin of soil organic matter
}

\author{
Éric LICHTFOUSE, Claudette LEBLOND, Martine Da SILVA and Françoise BEHAR
}

\begin{abstract}
Soil organic matter is a very complex mixture of compounds derived from the decay of living organisms such as plants, fungi and bacteria. The mechanisms that control the preservation of soil organic matter are poorly known. This is notably due to our scarce knowledge of the molecular structure of humin, the insoluble part of soil organic matter. Three major hypotheses have been proposed to explain the formation of soil organic matter: the plant alteration hypothesis, the microbial synthesis hypothesis and the chemical polymerisation hypothesis. Here we used a "biomarker" approach, developped mainly in sedimentary geochemistry, to gain some insight on the mechanims of preservation of soil organic matter. We analysed the compounds occurring in soil humin. We isolated humin from a maize crop soil by solvent extraction to remove free lipids, then by $\mathrm{NaOH}$ extraction to remove humic and fulvic acids, then by $\mathrm{HF} / \mathrm{HCl}$ treatment to remove minerals. The humin residue was then pyrolysed at $600^{\circ} \mathrm{C}$. The pyrolysate was fractionated into alkane/alkene and aromatic fractions by silica gel column chromatography. The fractions were analysed by gas chromatography coupled to mass spectrometry (GC-MS). We identified n-alkanes, n-alkenes, prist-1-ene, sterenes, hopenes and aromatic steroids in the humin pyrolysate. The results show that the stabilisation of soil humic substances may be achieved by selective preservation of lipids, involving three processes: encapsulation of small apolar molecules, chemical bonding of functionalized biomarkers, and preservation of straight-chain microbial polymers.
\end{abstract}

Key-words: soil organic matter; humin; plant wax n-alkane; maize; n-alkene; prist-1-ene; sterene; hopene; aromatic steroid; humic susbtances; aliphatic biopolymer; pyrolysis; GC-MS

Note from the author: this abstract was written in 2007 for indexing in the HAL archive. 
Revised version

Naturwissenschaften 85, 497-501, 1998.

doi: $10.1007 / \mathrm{s} 001140050538$

Correspondence: Dr. Eric Lichtfouse, INRA-CMSE-PME, 17, rue Sully, 21000 Dijon, France

Eric.Lichtfouse@dijon.inra.fr

\title{
Occurrence of biomarkers and straight-chain biopolymers in humin: implication for the origin of soil organic matter
}

\author{
Éric LICHTFOUSE ${ }^{1 *}$, Claudette LEBLOND ${ }^{2}$, Martine Da SILVA² and Françoise BEHAR ${ }^{2}$
}

1 LaboratoireSols et Environnement, INRA/ENSAIA-INPL, BP 172, 54505 Vandoeuvre-lès-Nancy, France.

2 Institut Français du Pétrole, Géochimie, BP 311, 92506 Rueil-Malmaison, France.

\section{Introduction}

Biomarkers are organic molecules found in petroleum, coal and sedimentary rocks. Their 'fossil' structure is indicative of their derivation from specific biological sources (1-3). For instance, the ubiquitous presence of hopanoids in fossil fuels has disclosed a notable bacterial input at the time of deposition of ancient sediments (4). Moreover, the occurrence of aliphatic biopolymers and various classes of lipids such as hopanoids and steroids in petroleum has evidenced that the main pathway of formation of sedimentary organic matter involves preservation of lipidic constituents.

In contrast, several processes have been proposed to explain the formation of soil organic components, named 'humic substances' (5-13). The plant alteration hypothesis states that lignin and other resistant plant materials in soil undergo only slight changes to form high molecular weight compounds. In the microbial synthesis hypothesis, microbes synthesise intracellularly high molecular weight humic substances. After the microbes die, these substances are released into the soil. Alternatively, in the chemical polymerisation hypothesis, small polar molecules from biomass decomposition and root exudates, e.g. amino acids, sugars, and phenols, are polycondensed to generate high molecular weight humic substances. However, the molecular structure of humic substances being poorly known and still a matter of debate $(14,15)$, other processes may explain how humification takes place. Indeed, several studies suggest that a substantial part of humin is made of lipidic components $(8,11,15-17)$. Here, we report the identification of $n$-alkanes, steroids, isoprenoid, hopanoids, and aliphatic biopolymers trapped in soil humin. This finding shows that the stabilisation of soil humic substances may be achieved by selective preservation of lipids, involving three processes : encapsulation of small apolar molecules, chemical bonding of functionalized biomarkers, and preservation of straight-chain microbial polymers.

Humin was isolated from a maize crop soil by solvent extraction to remove free lipids then by aqueous $\mathrm{NaOH}$ extraction to remove fulvic and humic acids. It was then treated with $\mathrm{HF} / \mathrm{HCl}$ using the classical kerogen isolation procedure to remove minerals (17). The $600^{\circ} \mathrm{C}$ pyrolysate of this residue was then fractionated into alkane-alkene and aromatic fractions (18) which were analysed by gas chromatography coupled to mass spectrometry. We identified linear, isoprenoid, steroid and hopanoid hydrocarbons (Figure 1).

* Author for correspondence 


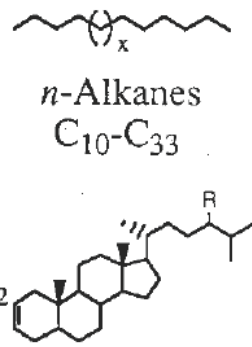

Ster-2-enes

$\mathrm{C}_{27}-\mathrm{C}_{29}$

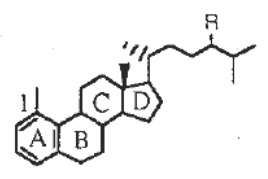

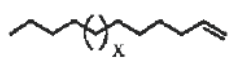

$n$-Alkenes

$\mathrm{C}_{10}-\mathrm{C}_{26}$

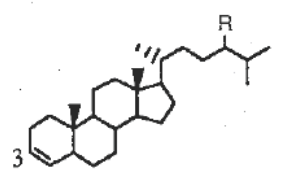

Ster-3-enes

$\mathrm{C}_{27}-\mathrm{C}_{29}$

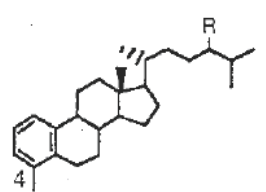

Ring-A-monoaromatic steroids

$\mathrm{C}_{27}-\mathrm{C}_{29}$

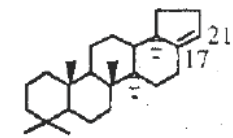

Hop-17(21)-ene (A) $\mathrm{C}_{27}$

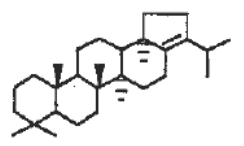

Hop-17(21) -ene (D)

$\mathrm{C}_{30}$

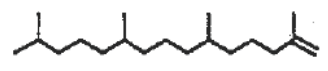

Prist-1-ene

$\mathrm{C}_{19}$

$\mathrm{R}=\mathrm{H}, \mathrm{CH}_{3}, \mathrm{C}_{2} \mathrm{H}_{5}$

Figure 1. Lipid biomarkers identified in the pyrolysate of soil humin.

\section{Linear alkanes}

Linear hydrocarbons can be classified into two categories (Figure 2). First, humin $n$-alkane/n-alkene doublets extending from $\mathrm{C}_{10}$ to $\mathrm{C}_{24}$ with no odd/even predominance. A such feature, with only few concomitant branched and cyclic alkanes, is typical of macromolecular cleavage products released by pyrolysis of sedimentary kerogens (19-21) and resistant aliphatic biopolymers (22). The possible formation of short-chain $n$-alkane $/ n$-alkene doublets from trapped $n$-alkanes can be excluded because, under similar conditions, plant-derived long-chain $n$-alkanes do not produce alkene homologues. Therefore, two other possible precursors could explain the formation of $n$-alkane/ $n$-alkene pairs : linear alcohols encapsulated by non-covalent binding and linear alcohols bound to the macromolecular matrix by ester bonds. Although the former is possible, a slight preference is given to the latter because in a previous study linear alcohols have been released by $\mathrm{KOH}$ hydrolysis of humic acids from the same soil.

Second, humin $n$-alkanes extending from $\mathrm{C}_{27}$ to $\mathrm{C}_{33}$ with a strong odd predominance, but without $n$-alkene homologues (Figure 2). This specific distribution, typical of plant waxes (23), is also found in 'free' alkane fractions of organic extracts from plant and soil (24). Therefore, since humin $\mathrm{C}_{27}-\mathrm{C}_{33} n$-alkanes has somehow 'survived' pyrolytic conditions without apparent chemical degradation, then these compounds must have been trapped in the humin matrix. Moreover, the mode of binding must have involved only weak forces because $n$-alkanes are apolar and nonfonctionalized. Besides, the formation of $\mathrm{C}_{27}-\mathrm{C}_{33} n$-alkanes by pyrolytic cleavage of ester-bound 
$n$-alkanols can be excluded because it should have yielded $\mathrm{C}_{27}-\mathrm{C}_{33} n$-alkenes homologues as well, which are not observed here.

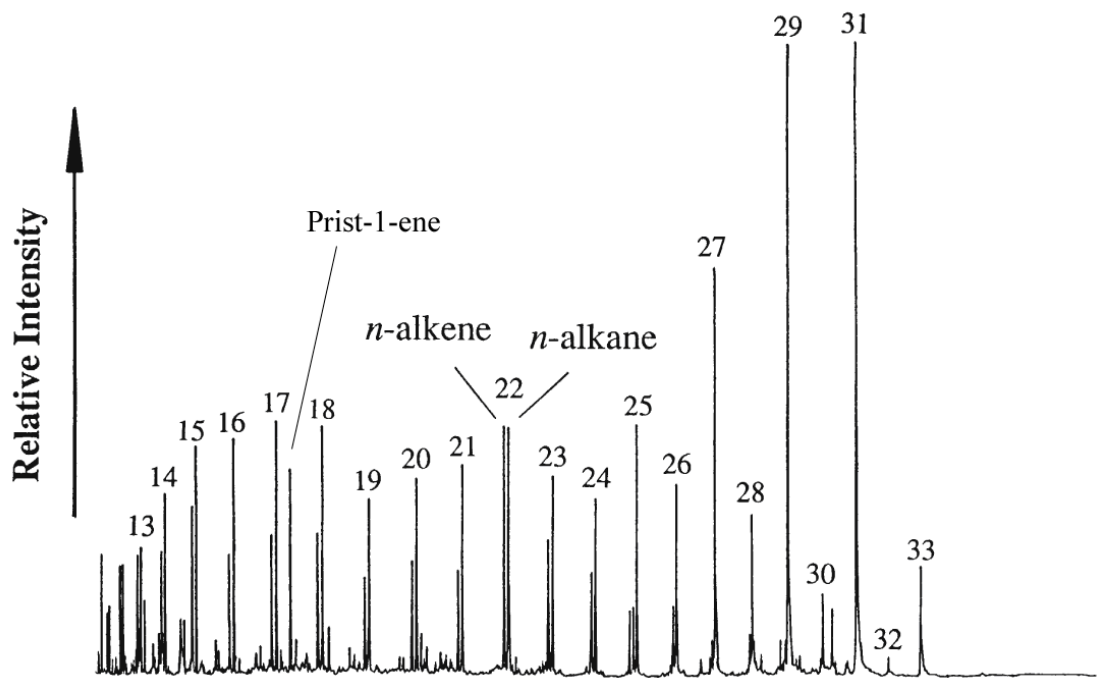

Time Direction

Figure 2. Alkane and alkenes released by pyrolysis of soil humin. Numbers refer to carbon numbers of $n$-alkanes and $n$-alkenes. Detailed procedures are reported elsewhere $(\mathbf{1 6 , 1 7 , 2 4})$. A sample of maize crop soil $(290 \mathrm{~g})$ was thoroughly extracted with $\mathrm{CHCl}_{3}-\mathrm{MeOH} 3 / 1 \mathrm{v} / \mathrm{v}$ to remove free lipids, then with $\mathrm{NaOH} 0.1 \mathrm{M}$ to remove fulvic and humic acids. The remaining matter (humin and minerals) was treated with $\mathrm{HCl}$ and $\mathrm{HF}$, then extracted with $\mathrm{CHCl}_{3^{-}}$ $\mathrm{MeOH}$ to yield $3.9 \mathrm{~g}$ of solid matter. This residue was pyrolyzed $5 \mathrm{~min}$. at $600^{\circ} \mathrm{C}$ in a gold tube under continuous argon flow. The pyrolysate was fractionated into alkane-alkene and aromatic fractions by silica gel column chromatography eluting pentane then pentane/methylene chloride $65 / 35 \mathrm{v} / \mathrm{v}$. The fractions were analysed using a HP 5890 gas chromatograph coupled to a VG Autospec mass spectrometer. Conditions : splitless injection; helium carrier gas; $60 \mathrm{~m} \times 0.2 \mathrm{~mm}$ capillary column coated with $0.2 \mu \mathrm{m}$ thickness methylpolysiloxane phase; oven temperature $50^{\circ} \mathrm{C}(1 \mathrm{~min}), 50^{\circ} \mathrm{C}$ to $140^{\circ} \mathrm{C}$ at $40^{\circ} / \mathrm{min}, 140^{\circ} \mathrm{C}$ to $320^{\circ} \mathrm{C}$ at $2^{\circ} / \mathrm{min}$ then $60 \mathrm{~min}$ isothermal; electronic impact $70 \mathrm{eV}, 31-650 \mathrm{amu}$ scan range. The following mass spectrometric data was obtained: mass/charge in amu (relative intensity in \%):

Sterenes: $5 \alpha$-Cholest-2-ene : $370\left(100, \mathrm{M}^{+}\right), 355\left(32, \mathrm{M}-\mathrm{CH}_{3}\right), 316\left(85, \mathrm{M}-\mathrm{C}_{4} \mathrm{H}_{6}\right.$ : retro Diels-Alder), 301 (10),

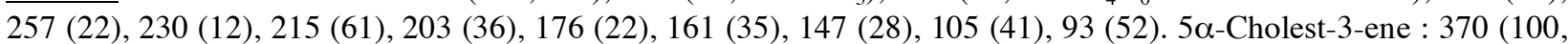

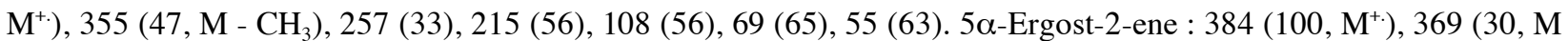
- $\mathrm{CH}_{3}$ ), 330 (64, M - $\mathrm{C}_{4} \mathrm{H}_{6}$ : retro Diels-Alder), 315 (7), 257 (20), 230 (9), 215 (53), 203 (32), 176 (28), 161 (23), 147

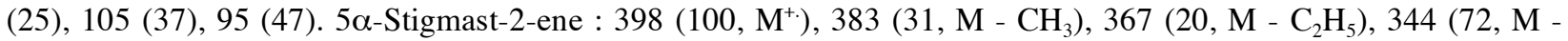

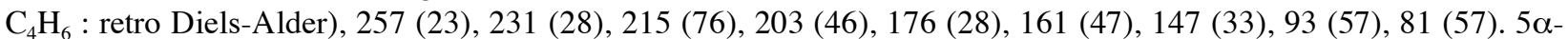
Stigmast-3-ene : $398\left(100, \mathrm{M}^{+}\right), 383$ (43, M - $\left.\mathrm{CH}_{3}\right), 257$ (21), 230 (11), 215 (52), 108 (37), 95 (43), 81 (36).

Monoaromatic steroids:_1-Methyl-19-nor-cholesta-1,3,5(10)-triene : $366\left(62, \mathrm{M}^{+}\right), 351\left(13, \mathrm{M}-\mathrm{CH}_{3}\right), 253(7), 226$ (11), 211 (100), 158 (35), 157 (51), 131 (34). 4-Methyl-19-nor-cholesta-1,3,5(10)-triene : $366\left(65, \mathrm{M}^{+}\right), 211$ (100), 158 (58), 157 (30), 131 (31). 1-Methyl-19-nor-stigmasta-1,3,5(10)-triene : $394\left(67, \mathrm{M}^{+}\right), 379\left(19, \mathrm{M}-\mathrm{CH}_{3}\right), 253(7)$, 226 (14), 211 (100), 197 (13), 185 (15), 170 (34), 158 (36), 157 (61), 143 (30), 131 (48).

Hopanoids: 22, 29, 30-Trisnorhop-17(21)-ene (A) : 368 (28, $\left.\mathrm{M}^{+}\right), 353$ (6, M - $\left.\mathrm{CH}_{3}\right), 231$ (75), 191 (100), 161 (49), 147 (50), 133 (29), 95 (48). Hop-17(21)-ene (D) : $410\left(56, \mathrm{M}^{+}\right), 395\left(25, \mathrm{M}-\mathrm{CH}_{3}\right), 367\left(100, \mathrm{M}_{-} \mathrm{C}_{3} \mathrm{H}_{7}\right), 231$ (71), 191 (67), 189 (28), 175 (30), 161 (58), 135 (60), 121 (43), 93 (22), 81 (27). 17ß-22,29,30-Trisnorhopane (B) : 370 $\left(19, \mathrm{M}^{+}\right), 355$ (11, M - $\left.\mathrm{CH}_{3}\right), 191$ (86), 177 (13), 163 (22), 149 (100), 136 (18), 123 (19), 109 (22), 95 (56), 81 (49). 


\section{Pristene}

The most abundant isoprenoid alkane has been identified as prist-1-ene (Figure 1,2) by comparison of chromatographic and mass spectrometric data with literature $(21,25)$. Prist-1-ene is most likely derived from the phytyl side-chain of chlorophyll $(3,25)$ following pyrolytic cleavage of ester-bound phytol. A such finding indicates that chlorophyll moieties could be incorporated into the complex macromolecular matrix during humification processes. Moreover, prist-1-ene may also be used as a source biomarker for plant input.

\section{Steroids and hopanoids}

The reconstructed ion current at $\mathrm{m} / \mathrm{z} 215$ (Figure 3) of the alkane-alkene fraction reveals the occurrence of $\mathrm{C}_{27}-\mathrm{C}_{29} \Delta^{2}$ - and $\Delta^{3}$-sterenes which were identified by comparison of their chromatographic and mass spectrometric characteristics with literature data. More specifically, the major 215 ion fragment indicates the presence of a double bond in the steroid $\mathrm{A}, \mathrm{B}$ or $\mathrm{C}$ cycles (26-28). $\Delta^{2}$-sterenes give a typical ion fragment at M - 54 corresponding to retro DielsAlder loss of butadiene (29). $\Delta^{3}$-sterenes show mass spectral and chromatographic data which are in agreement with reported data (26) and which differs from other sterenes (26-28,30). Furthermore, a $\mathrm{C}_{27}-\mathrm{C}_{29}$ series of ring $\mathrm{A}$ monoaromatic steroid bearing a methyl group at either position 1 or 4 (Figure 1) was identified using the reconstructed ion current at $\mathrm{m} / \mathrm{z} 211$ of the aromatic fraction. The 1-methyl and 4-methyl are clearly distinguished on mass spectral and chromatographic grounds (31), displaying for instance a 157/158 ion fragment ratio $>1$ and $<1$, respectively. The reconstructed ion current at $\mathrm{m} / \mathrm{z} 191$ of the alkane-alkene fraction reveals the occurrence of $\mathrm{C}_{27}$ and $\mathrm{C}_{30} \Delta^{17(21)}$-hopenes, and $\mathrm{C}_{27} 17 \beta$-hopane (Figure 4), which were identified by comparison of their mass spectra and chromatographic retention times with literature data (26, $32)$.

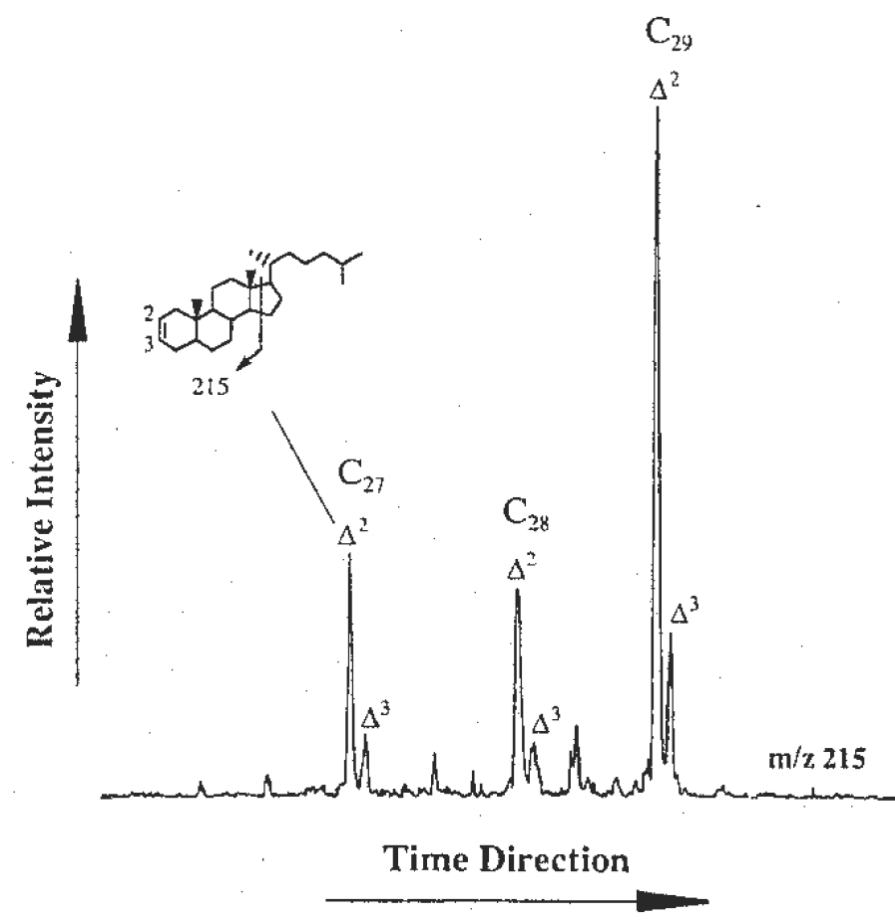

Figure 3. Reconstructed ion chromatogram at $\mathrm{m} / \mathrm{z} 215$ of the pyrolysate alkane-alkene fraction showing sterenes released by pyrolytic cleavage of humin. 
The occurrence of sterene, aromatic steroid, hopene and sterane in humin pyrolysates can be explained in two ways. These molecules may have been already present in the soil before pyrolysis. However, we did not detect them in soil extracts by gas chromatography coupled to mass spectrometry. Alternatively, they must have been produced during pyrolysis by dehydration of functionalized precursors. For example, sterenes and aromatic steroids could be generated either from ester bound sterols or from encapsulated sterols, as suggested by the occurrence of free and humic acid-bound sterols in the same soil (33). Sterenes can be formed by reaction of sterols at $140^{\circ} \mathrm{C}$ using a clay catalyst (34). Moreover, the generation of aromatic steroids by slow thermal maturation of sterols is a well-known process occurring in sedimentary rocks (22).

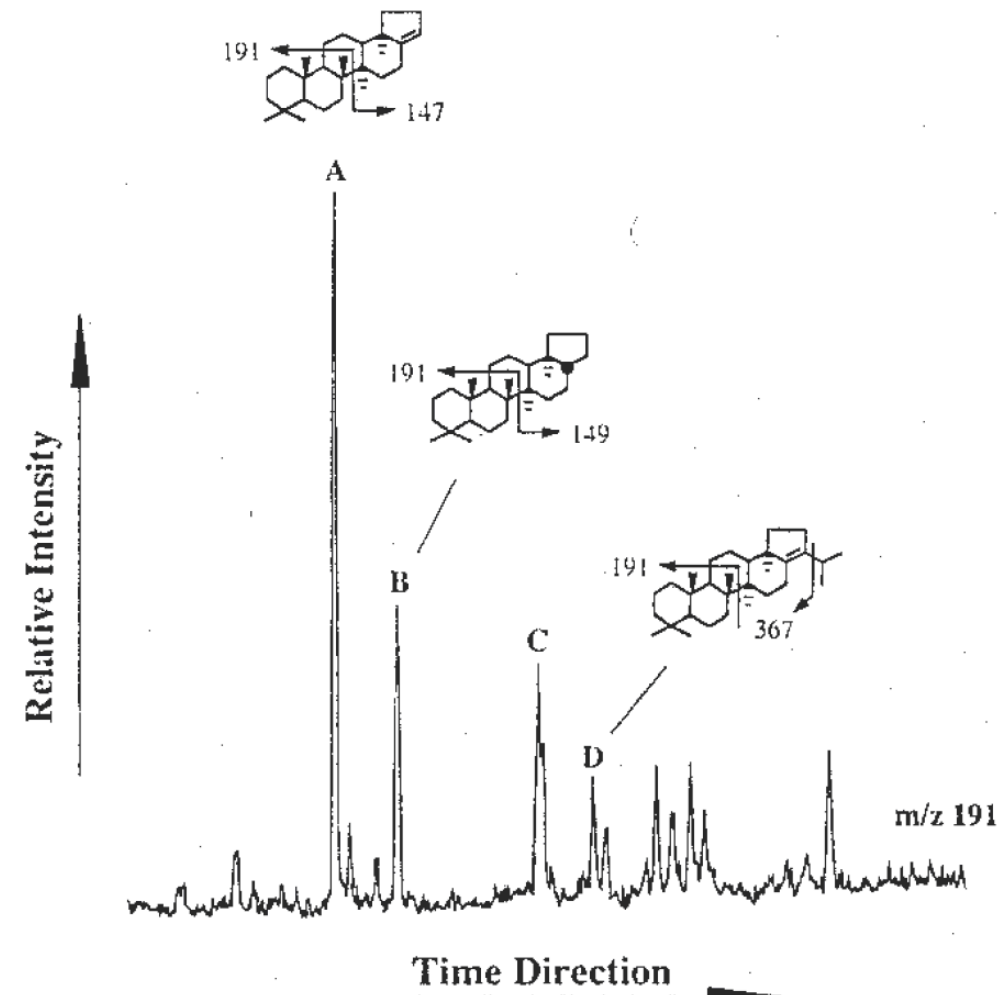

Figure 4. Reconstructed ion chromatogram at m/z 191 of the pyrolysate alkane-alkene fraction showing hopenes released by pyrolytic cleavage of humin.

\section{Humification}

The main current hypothesis on the formation of humic substances, proposed by Maillard in 1917 (5), involves biodegradation of biopolymers, e.g. lignin and cellulose, followed by recondensation of water-soluble microbial metabolites such as phenols, amino acids, and sugars into an insoluble high molecular-weight network (9). The insolubility of humin is also thought to be caused by its complexation with inorganic materials from soils (6). However, the exact molecular structure of most humic substances being so far poorly known, other processes may explain how humification takes place. Indeed, the presence of various lipid classes in humin pyrolysates (Figure 1) demonstrate that the precursors of these substances were sequestred into the humin organic network. The trapping of lipidic substances in soil could involve several alternative mechanisms (Figure 5). 


\section{Physical sequestration}

The presence in humin pyrolysate of plant-derived long-chain $n$-alkanes as non-cleavage products shows that small apolar molecules can be encapsulated into the organic matrix as a result of sterical hindrance. This physical sequestration is based upon relatively weak interactions such as van der Waals and coulombic forces. Weak, noncovalent interactions can lead to the encapsulation of organic molecules which will not be extracted without drastic treatments, e.g. alkaline hydrolysis and pyrolysis. It is in full agreement with the reported identification of various bound $n$-alkanes in humic acids, coals and kerogens $(21,35)$.

\section{Resistant straight-chain biopolymers}

The presence in humin pyrolysate of short-chain $n$-alkane/n-alkene pairs as cleavage products confirms the occurrence of resistant straight-chain biopolymers in soils. Indeed, such biopolymers have been morphologically identified in humin by transmission electron microscopy (17). Their derivation from soil microbes has been assessed by ${ }^{13} \mathrm{C}$ analysis (36). The selective preservation of these biopolymers is due both to their wrapped assemblage in ultralaminae (17) and to their highly aliphatic macromolecular skeleton, making them very resistant to chemical and biological degradation. Altogether, these findings show evidence that a part of soil organic matter is formed by selective preservation of resistant straight-chain biopolymers from soil microbes.

\section{Chemical sequestration}

The presence in humin pyrolysate of isoprenoid, steroid and hopanoid alkenes shows that the precursors of these substances were bound to the humin matrix prior pyrolysis (Figure 5). Further, since the biological precursors of alkenes are alcohols, e.g. phytol, sterols and hopanols, this chemical sequestration is likely to have been done by formation of ester and ether binding with other humic constituents. Indeed, a similar process involving xenobiotics has been evidenced recently at the molecular level using selective chemical reagents (37, 38). Alternatively, alcohols could have been encapsulated in the humin matrix by weak forces then dehydrated during pyrolysis.

In summary, our findings give evidence for three additional pathways of stabilisation of soil organic matter (Figure 5) : selective preservation of resistant straight-chain biopolymers; physical sequestration of small lipids by encapsulation; and chemical sequestration by strong binding of biomarkers with the humic substances. These processes are relevant to issues concerning the behaviour of apolar xenobiotics in soils and other media such as food, waters, and sediments. Indeed, many industrial and agricultural chemicals are structurally similar to humus constituents and, therefore, may be incorporated into soil organic matter during humification. For instance, polychlorinated biphenyls (PCB) adsorption has been related to organic matter content, though exact mechanisms of incorporation are not yet known (6,9). Bound 1,1,1-trichloro-2,2-bis( $p$ chlorophenyl)ethane (DDT) has also been associated with the lipophilic fraction of organic matter (6). Furthern the molecular characterisation of ester binding of PCB and PAH metabolites has been nicely evidenced using labelled $\mathrm{Na}^{18} \mathrm{OH}$ cleavage of various humic substances $(37,38)$. For the characterisation of weak interactions, a novel approach using ${ }^{13} \mathrm{C}$ NMR techniques was used to show noncovalent binding of acenaphthenone with fulvic acid (39). Thus, the physical and chemical sequestration processes outlined in this study could explain, at least partly, why 
apolar pesticides can be trapped within the soil, then later released in groundwater by physicochemical alteration of the soil structure, e.g. tillage and water-washing.

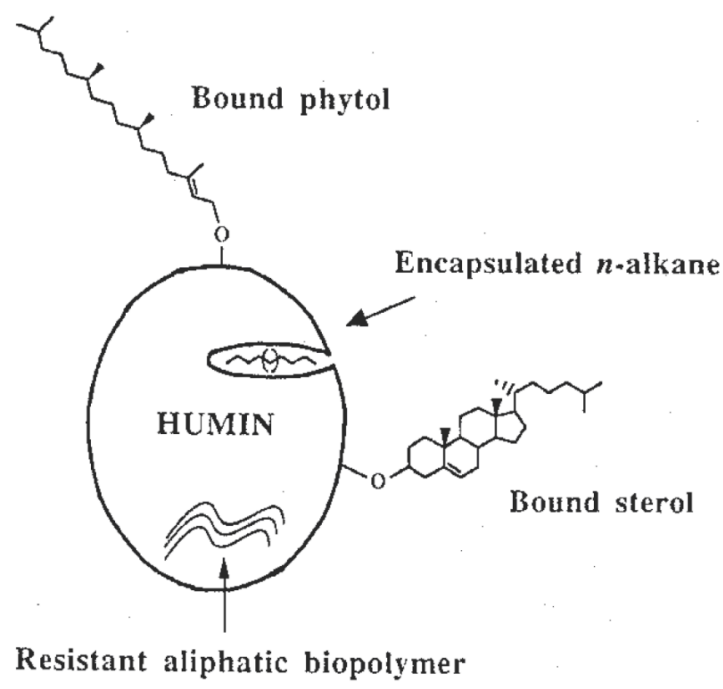

Figure 5. Schematic representation of humin explaining the stabilization of soil organic matter either by encapsulation of small apolar molecules (physical sequestration), or by binding of functionalized biomarkers (chemical sequestration), or by selective preservation of aliphatic biopolymers.

\section{REFERENCES}

1. Albrecht, P., Ourisson, G.: Angew. Chem. internat. Edit. 10, 209-225 (1971)

2. Mackenzie, A. S., Brassell, S., Eglinton, G, Maxwell, J. R.: Science 217, 491-505 (1982)

3. Peters, K. E., Moldowan, J. M.: The Biomarker Guide. Englewood Cliffs: Prentice Hall: 1993

4. Ourisson, G., Albrecht P.: Acc. Chem. Res. 25, 398-402 (1992)

5. Maillard, L. C.: Ann. Chim. Paris 7, 113-152 (1917)

6. Bollag, J.-M., Loll, M. J.: Experientia 39, 1221-1231 (1983)

7. Rice, J. A., MacCarthy, P.: Geoderma 43, 65-73 (1988)

8. Beyer, L.: Z. Pflanzenernähr. Bodenk. 159, 527-539 (1996)

9. Rashid M. A.: Geochemistry of Marine Humic Compounds. Berlin: Springer 1985

10. Hayes, M. H. B., MacCarthy, P., Malcolm, R. L., Swift, R. S. (Eds.): Humic Substances II. In Search of Structure. Chichester: Wiley 1989

11. Hatcher, P., Maciel, G. E., Dennis, L. W.: Org. Geochem. 3, 43-48 (1981)

12. Schulten, H.-R., Schnitzer, M.: Naturwissenschaft. 80, 29-30 (1993)

13. Schnitzer, M., Khan, S. U.: Soil Organic Matter. Amsterdam: Elsevier 1978.

14. De Leeuw, J. W., Hatcher, P. G.: Naturwissenschaft. 79, 330-331 (1992)

15. Almendros, G., Sanz, J., Gonzáles-Vila, F. J., Martin, F. Naturwissenschaft. 78, 359-362 (1991)

16. Lichtfouse, E., Chenu, C., Baudin, F., Leblond, C., Da Silva, M., Behar, F., Derenne, S.,

Largeau, C., Wehrung, P., Albrecht, P.: Org. Geochem. (1998) in press

17. Lichtfouse, E., Chenu, C., Baudin, F.: Org. Geochem. 25, 263-265 (1996)

18. Behar, F., Leblond, C., Saint-Paul, C.: Rev. Inst. Fr. Pétr. 44, 387-411 (1989)

19. Fukushima, K. Geochem. J. 16, 43-49 (1982)

20. Behar, F., Pelet, R., Roucache, J. Org. Geochem. 6, 587-595 (1984) 
21. Behar, F. Vandenbroucke, M. Org. Geochem. 13, 927-938 (1988)

22. Derenne, S., Le Berre, F., Largeau, C., Hatcher, P., Connan, J., Raynaud, J. F.: Org. Geochem. 19, 345-350 (1992)

23. Eglinton, G., Hamilton, R. J.: Science 156, 1322-1335 (1967)

24. Lichtfouse, E., Bardoux, G., Mariotti, A., Balesdent, J., Ballentine, D. C., Macko, S. A.:

Geochim. Cosmochim. Acta 61, 1891-1898 (1997)

25. Larter, S. R., Solli, H., Douglas, A. G., De Lange, F., De Leeuw, J. W. Nature 279, 405-408 (1979).

26. Philp, R. P.: Fossil Fuel Biomarkers. Amsterdam: Elsevier 1985

27. Peakman, T. M., Ten Haven, H. L., Rechka, J. R., De Leeuw, J. W., Maxwell, J. R.:

Geochim. Cosmochim. Acta 53, 2001-2009 (1989)

28. Rubinstein, I., Sieskind, O., Albrecht, P.: J. C. S. Perkin Trans I, 1833-1836 (1975)

29. Dastillung, M., Albrecht, P. Nature 269, 678-679 (1977)

30. Peakman, T. M., De Leuuw J. W., Rijpstra, W. I. C.: Geochim. Cosmochim. Acta 56, $1223-$ 1230 (1992)

31. Hussler, G., Chappe, B., Wehrung, P., Albrecht, P.: Nature 294, 556-558 (1981)

32. Kimble, B. J., Maxwell, J. R., Philp, R. P., Eglinton, G., Albrecht, P., Ensminger, A., Arpino, P., Ourisson, G.: Geochim. Cosmochim. Acta 38, 1165-1181 (1974)

33. Lichtfouse, E. Unpublished results.

34. Sieskind, O., Joly, G., Albrecht, P. Geochim. Cosmochim. Acta 43, 1675-1679 (1979)

35. Schnitzer, M., Neyroud, J. A.: Fuel 54, 17-19 (1975). Schnitzer, M., Hindle, C. A., Meglic, M.: Soil Sci. Soc. Am. J. 50, 913-919 (1986)

36. Lichtfouse, E., Dou, S., Girardin, C., Grably, M., Balesdent, J., Behar, F., Vandenbroucke, M.: Org. Geochem. 23, 865-868 (1995)

37. Richnow, H. H., Seifert, R., Hefter, J., Kästner, M., Mahro, B., Michaelis, W.: Org. Geochem. 22, 671-681 (1994)

38. Michaelis, W., Richnow, H. H., Seifert, R.: Naturwissenschaft. 82, 139-142 (1995)

39. Nanny, M. A., Bortiatynski, J. M., Hatcher, P. G.: Environ. Sci. Technol. 31, 530-534 (1997) 